\title{
Integration of Technology among Saudi EFL Teachers
}

\author{
Amal Almalki ${ }^{1}$ \\ ${ }^{1}$ King Abdulaziz University, TESOL, Saudi Arabia \\ Correspondence: Amal Almalki, King Abdulaziz University, TESOL, Saudi Arabia.
}

Received: June 2, 2020

Accepted: July 17, 2020

Online Published: July 24, 2020

doi: $10.5539 /$ elt.v13n8p160

URL: https://doi.org/10.5539/elt.v13n8p160

\begin{abstract}
In the field of education, technology is currently considered a new trend. This study aims to examine the factors that affect the integration of new technologies in EFL classrooms. Factors considered include teacher's age, teacher's level of technological proficiency, and teacher's perception of technology. To achieve this, the study involved a questionnaire consisting of 21 items and a total of 38 Saudi EFL teachers participated in it.

The results indicate that there is no significant relationship between teacher age and technology integration. However, both teachers' level of proficiency in technology and teacher's perception of technology were significantly related to technology integration in Saudi EFL classrooms.

It is recommended to provide teachers with professional development and support in technology integration and to supply classrooms with resources such as computers and smart boards.
\end{abstract}

Keywords: technology integration, teacher age, technological proficiency, teacher perceptions, EFL teachers

\section{Introduction}

Technology integration is widely considered one of the most important method used by teachers. Technology integration in classrooms refers to the enhancement of the educational environment with technology (Dockstader, 2008, as cited in Ahmadi, 2018). Teachers can use technology to facilitate the learning process and employ different resources to motivate different learners (Ahmadi, 2018). This method is thus beneficial for both higher and lower achievers. For instance, technology can enhance the learning process of higher achievers; simultaneously, technology can help lower achievers access extra materials to help them obtain a more accurate understanding of the lesson. Moreover, by using technology, students can access far more information than without it, and they can gain control over their learning process (Pourhosein Gilakjani \& Sabouri, 2014).

Although technology integration in language classrooms is highly beneficial, several factors affect its implementation. Many of these factors are related to teachers, as teachers are generally the leaders in the learning process. The factors explored in this study include the teacher's age, the teacher's level of technology proficiency, and the teacher's perception of technology. All three factors can affect the implementation of technology in the classroom either positively or negatively.

The present paper aims to examine some key factors that affect the integration of new technologies in the classroom, namely teachers' age, level of technology proficiency, and perception of technology.

\section{Literature Review}

Studies have identified a wide variety of factors that affect the implementation of new technologies in classrooms. Of these studies, a majority have found three teacher-related factors to have the most significant effect on the implementation of technology: teachers' age, level of technology proficiency, and perception of technology.

\subsection{Teacher Age and Technology Integration}

The age of the teacher is one of the main factors that affect the integration of new technology in the classroom. Henry (2008) investigated the relationship between the age, gender, and personality of university instructors in the implementation of technology. The findings illustrate the positive effect of age on technology implementation; namely, the study indicated that older teachers tend to implement technology in their classes to a greater extent than younger teachers. According to Henry (2008), older members may be more comfortable 
with their content, which in turn allows them to feel more confident using new teaching methods that involve technology.

However, some studies have suggested that age does not affect the use of technology in class. Mahdi and Al-Dera (2013) conducted a study among Saudi EFL teachers working at Najran University to explore the impact of teachers' age, experience, and gender on the integration of information and communication technology into language teaching. The findings of the study did not illustrate any effect of the teacher's age on the use of technology. However, this study was not conducted on a large sample of participants, so the findings cannot be generalized. Similarly, the teacher's age did not play a significant role in technology integration in a study conducted by Tweed (2013).

\subsection{Teacher Level of Technology Proficiency and Technology Integration}

Another contributing factor is the level of teachers' technology proficiency. Technology proficiency is an individual's ability to use different software applications effectively (Zhao, Pugh, Sheldon, \& Byers, 2002). Teachers' capability and confidence, or lack thereof, when using different types of technology will affect technology integration in class. Namely, if the teacher lacks capability and confidence in using technology, the teacher will not be able to implement technology in class (Jones, 2004). Al-Asmari (2005) conducted a study of EFL teachers in four main technology colleges in Saudi Arabia. The participants showed low levels of technology proficiency. The study indicated that the participants had rarely even used the internet as an instructional tool. Nonetheless, the teachers in this study showed an interest in using technology, acknowledging it could be helpful if they were able to use it properly in teaching; the study therefore concluded that it is important to provide teachers with training courses in technology integration (Al-Asmari, 2005). Other research has suggested that teachers who receive technology-related professional development tend to have higher levels of technology integration in their classrooms (Hastings, 2009).

\subsection{Teacher Perceptions and Technology Integration}

In addition, teachers' perception of the use of technology in class is a key factor that affects technology integration. It has been found that teachers' beliefs are directly linked to the teaching methodology that they apply in their classroom (Kagan, 1992, as cited in Alsaied, 2016). In other words, if the teacher has a positive perception of technology integration, the teacher is more likely to adopt this methodology and apply it effectively to English language teaching.

Research has shown that teachers perceive technology integration differently. Some teachers perceive technology as a tool that improves and supports learning (Mollaie \& Riasati, 2013). A study conducted by Aydin (2013) found that most of the teachers agreed that technology enhanced learners' understanding of new concepts and helped them to think creatively. However, Saqlani and Mahmood (2013) reported that although participants had a positive view of technology integration, they were anxious and worried about using technology in the teaching process. The reason for this anxiety was that teachers did not have the ability to overcome the technical difficulties that they faced when applying new technologies. The participants agreed that adequate training would help them to be more confident in integrating technology (Saqlani \& Mahmood, 2013). Similarly, Çebi (2018) demonstrated that participants in his study had a positive attitude towards technology integration, but a lack of training, resources, and knowledge that might hinder utilization of technology in their classes.

Research findings have revealed that factors such as teachers' age, level of technology proficiency, and perception of technology affect the implementation of technology in the classroom; however, few researchers have examined the combination of these three factors among Saudi EFL teachers. Therefore, the main purpose of this study is to explore the relationship between these factors and Saudi EFL teachers' integration of new technologies. This quantitative study will be guided by the following research questions:

1. What is the relationship between teacher age and technology integration in EFL classrooms in the Saudi context?

2. What is the relationship between teachers' level of technology proficiency and technology integration in EFL classrooms in the Saudi context?

3. What is the relationship between teachers' perceptions of technology and technology integration in EFL classrooms in the Saudi context? 


\section{Methodology}

\subsection{Participants}

Thirty-eight Saudi EFL teachers from various educational phases participated in this study. Some participants were under 40 years old, and some were over 40. All participants were non-native speakers of English.

\subsection{Research Method}

A quantitative research approach was adopted to answer the research questions. According to Dornyei (2007), the aim of the quantitative approach is to determine and measure the relationship between different variables, which is the aim of the current study. A questionnaire was adopted and developed based on a project conducted by the Centre for the Study of Learning and Performance (CSLP) at Concordia University in Montreal.

\subsection{Procedure}

The researcher used the Google online questionnaire tool as this tool allowed the questionnaire to be easily distributed among teachers. The questionnaire included 21 items that aimed to examine three factors among the Saudi EFL teachers: their age, level of technology proficiency, and perceptions of technology integration. The questionnaire was designed on a five-point Likert-scale ranging from 1 (strongly agree) to 5 (strongly disagree). A pilot study was conducted to ensure the validity of the results. A Cronbach alpha was then used to determine the reliability of the questionnaire, offering a score of 0.93 .

\subsection{Analysis of Method}

The researcher analysed the data using the Statistical Package for Social Sciences (SPSS) software, which is a powerful software used to analyse complex statistical data (Pallant, 2011). The researcher started with descriptive statistics to find the means, standard deviations, and frequency of the responses. Moreover, the results of this test showed how responses coordinated with the participants under the age of 40 versus those over the age of 40. A Pearson correlation test was then conducted to determine the relationship between teacher age, level of technology proficiency, and perception of technology integration in the classroom. A correlation analysis was used to describe the relationship between the variables and whether any correlation was strong or weak (Pallant, 2011).

\section{Results}

The researcher aimed to examine three variables (teachers' age, level of technology proficiency, and perception of technology) and their relation with technology integration in Saudi EFL classrooms. In order to obtain an overview and describe the data received by participants, the researcher started with descriptive statistics and then conducted a Pearson correlation coefficient test to find the relationship between different variables.

\subsection{Descriptive Statistics}

The descriptive data included the mean, standard deviation, and frequency of the responses received by the participants. Table 1 provides a summary of the participants' ages.

Table 1. Teachers' ages

\begin{tabular}{lll}
\hline Groups & Number of participants & Percentage \\
\hline Under 40 & 25 & 65.8 \\
Over 40 & 13 & 34.2 \\
Total & 38 &
\end{tabular}

Table 1 shows that a total of 38 teachers participated in this study, 25 of whom were under 40 years old, while 13 were over the age of 40 . The researcher divided the participants into these two age groups to help determine if the age of the teacher had an impact on technology integration in Saudi EFL classrooms.

In terms of exploring teachers' technology proficiency, Table 2 provides a summary of participants' responses. 
Table 2. Descriptive statistics of teachers' technology proficiency

\begin{tabular}{|c|c|c|c|c|c|c|c|}
\hline \multirow[t]{3}{*}{ Items } & \multicolumn{7}{|l|}{$\%$} \\
\hline & & & & & & $\mathrm{M}$ & SD \\
\hline & SA & A & $\mathrm{N}$ & $\mathrm{D}$ & SD & & \\
\hline 1. I can apply what I know about technology in the classroom. & 65.8 & 13.2 & 10.5 & 5.3 & 5.3 & 1.71 & 1.18 \\
\hline $\begin{array}{l}\text { 2. I am able to use technology as an instructional aid and have } \\
\text { integrated technology into the curriculum. }\end{array}$ & 55.3 & 21.1 & 13.2 & 5.3 & 5.3 & 1.84 & 1.17 \\
\hline 3. I can use many different computer applications. & 47.4 & 15.8 & 23.7 & 7.9 & 5.3 & 2.08 & 1.23 \\
\hline $\begin{array}{l}\text { 4. I am proficient in using a wide variety of computer } \\
\text { technologies. }\end{array}$ & 34.2 & 23.7 & 18.4 & 13.2 & 10.5 & 2.42 & 1.36 \\
\hline 5. I integrate computer technologies into my teaching activities. & 39.5 & 31.6 & 21.1 & 5.3 & 2.6 & 2.00 & 1.04 \\
\hline $\begin{array}{l}\text { 6. I feel that I need more training in the use of technology for } \\
\text { teaching. }\end{array}$ & 2.6 & 18.4 & 28.9 & 18.4 & 31.6 & 3.58 & 1.20 \\
\hline 7. It is hard for me to implement technology in class. & 13.2 & 21.1 & 23.7 & 7.9 & 34.2 & 2.45 & 1.38 \\
\hline
\end{tabular}

As shown in Table 2, the results indicate that teachers have a high level of technology proficiency. For example, the responses to statements 1 and 2 show that over half of the teachers have the ability to integrate technology into their classes. Moreover, the last two statements suggest that teachers feel proficient in using technology.

Furthermore, in relation to teachers' perceptions of technology implementation, Table 3 offers an analysis of the responses received by the participants.

Table 3. Descriptive statistics of the teachers' perceptions of technology

\begin{tabular}{|c|c|c|c|c|c|c|c|}
\hline \multirow[t]{3}{*}{ Items } & \multicolumn{7}{|l|}{$\%$} \\
\hline & & & & & & \multirow[t]{2}{*}{ M } & \multirow[t]{2}{*}{ SD } \\
\hline & SA & A & $\mathrm{N}$ & $\mathrm{D}$ & SD & & \\
\hline $\begin{array}{l}\text { 1. The use of technology eases the pressure on me as a } \\
\text { teacher. }\end{array}$ & 65.8 & 13.2 & 5.3 & 5.3 & 10.5 & 1.82 & 1.37 \\
\hline 2. Technology plays an important role in the learning process. & 71.1 & 15.8 & 2.6 & 2.6 & 7.9 & 1.61 & 1.19 \\
\hline $\begin{array}{l}\text { 3. The use of technology improves students' understanding of } \\
\text { the lesson. }\end{array}$ & 57.9 & 23.7 & 10.5 & 2.6 & 5.3 & 1.74 & 1.10 \\
\hline 4. Technology is a valuable instructional tool. & 68.4 & 13.2 & 7.9 & 0 & 10.5 & 1.71 & 1.29 \\
\hline $\begin{array}{l}\text { 5. Technology motivates students to get more involved in the } \\
\text { learning process. }\end{array}$ & 68.4 & 15.8 & 7.9 & 5.3 & 2.6 & 1.58 & 1.03 \\
\hline $\begin{array}{l}\text { 6. The use of technology results in students neglecting } \\
\text { important traditional learning resources (e.g., library books). }\end{array}$ & 0 & 18.4 & 18.4 & 26.3 & 36.8 & 3.82 & 1.13 \\
\hline $\begin{array}{l}\text { 7. Technology requires software-skills training that is too } \\
\text { time-consuming. }\end{array}$ & 7.9 & 15.8 & 18.4 & 34.2 & 23.7 & 3.50 & 1.24 \\
\hline
\end{tabular}

The results presented in Table 3 indicate that teachers perceive technology as something positive. The majority of teachers strongly agreed with statements 1-5. Furthermore, a high number of teachers disagreed and strongly disagreed with negative statements 6 and 7.

Finally, a summary of the independent variable, which involves exploring technology implementation in the classroom, is shown in Table 4. 
Table 4. Descriptive statistics for technology implementation

\begin{tabular}{|c|c|c|c|c|c|c|c|}
\hline \multirow[t]{3}{*}{ Items } & \multicolumn{7}{|l|}{$\%$} \\
\hline & & & & & & $\mathrm{M}$ & SD \\
\hline & SA & A & $\mathrm{N}$ & $\mathrm{D}$ & SD & & \\
\hline $\begin{array}{l}\text { 1. I use a variety of strategies to implement technology into } \\
\text { my curriculum. }\end{array}$ & 36.8 & 34.2 & 21.1 & 2.6 & 5.3 & 2.05 & 1.08 \\
\hline $\begin{array}{l}\text { 2. I plan and integrate technology-based learning activities } \\
\text { that promote student engagement in higher-order thinking } \\
\text { skills. }\end{array}$ & 42.1 & 31.6 & 7.9 & 13.2 & 5.3 & 2.08 & 1.23 \\
\hline 3. I try to use as many computer applications as I can. & 31.6 & 28.9 & 21.1 & 7.9 & 10.5 & 2.37 & 1.30 \\
\hline 4. I use new technologies in class. & 36.8 & 26.3 & 18.4 & 13.2 & 5.3 & 2.24 & 1.24 \\
\hline 5. I introduce my students to new technologies. & 39.5 & 36.8 & 15.8 & 2.6 & 5.3 & 1.97 & 1.07 \\
\hline $\begin{array}{l}\text { 6. I integrate technology that helps to improve students' } \\
\text { understanding. }\end{array}$ & 60.5 & 18.4 & 13.2 & 5.3 & 2.6 & 1.71 & 1.06 \\
\hline 7. Technology is a fundamental component of my class. & 50.0 & 15.8 & 23.7 & 5.3 & 5.3 & 2.00 & 1.20 \\
\hline
\end{tabular}

The results in Table 4 show that teachers integrate technology into their classrooms. Some teachers also view technology as an essential and fundamental tool in class.

\subsection{Pearson Correlation Test}

This paper was guided by three questions and, in order to answer them, a Pearson correlation coefficient test was needed. Table 5 provides a summary of the correlation between the variables.

Table 5. Correlations

\begin{tabular}{lllllll}
\hline & & Age & Perceptions & Proficiency & Implementation \\
\hline Age & Pearson Correlation & 1 & .057 & .260 & .110 \\
& Sig. (2-tailed) & & .734 & .115 & .512 \\
Perceptions & $\mathrm{N}$ & 38 & 38 & 38 & 38 \\
& Pearson Correlation & .057 & 1 & $.671^{* *}$ & $.816^{* *}$ & \\
& Sig. (2-tailed) & .734 & & .000 & .000 \\
\multirow{5}{*}{ Proficiency } & $\mathrm{N}$ & 38 & 38 & 38 & 38 \\
& Pearson Correlation & .260 & $.671^{* *}$ & 1 & $.876^{* *}$ \\
& Sig. (2-tailed) & .115 & .000 & & .000 \\
& $\mathrm{~N}$ & 38 & 38 & 38 & 38 \\
& Pearson Correlation & .110 & $.816^{* *}$ & $.876^{* *}$ & 1 \\
& Sig. (2-tailed) & .512 & .000 & .000 & \\
& $\mathrm{~N}$ & 38 & 38 & 38 & 38
\end{tabular}

**. Correlation is significant at the 0.01 level (2-tailed).

The first research question asked the following: "What is the relationship between teacher age and technology integration in EFL classrooms in the Saudi context?" The results indicate a weak positive correlation between the teacher age $(\mathrm{M}=1.34, \mathrm{SD}=.481)$ and technology integration $(\mathrm{M}=12.70, \mathrm{SD}=5.82)$ and a correlation that was not statistically significant $[\mathrm{r}=.110, \mathrm{p}=512]$.

The second research question asked "What is the relationship between teachers' level of technology proficiency and technology integration in EFL classrooms in the Saudi context?" The results show a strong positive correlation between the teacher's level of technology proficiency $(\mathrm{M}=13.98, \mathrm{SD}=5.21)$ and technology integration $(\mathrm{M}=12.70, \mathrm{SD}=5.82)$ and a correlation that was statistically significant $[\mathrm{r}=.876, \mathrm{p}=000]$.

The final question was as follows: "What is the relationship between teachers' perceptions towards technology and technology integration in EFL classrooms in the Saudi context?" The results revealed a strong positive 
correlation between the teacher perception $(\mathrm{M}=12.76, \mathrm{SD}=5.29)$ and technology integration $(\mathrm{M}=12.70, \mathrm{SD}=5.82)$ and a correlation that was statistically significant $[\mathrm{r}=.816, \mathrm{p}=000]$.

\section{Discussion}

This study was guided by three questions that asked respectively how three factors (teachers' age, technology proficiency, and perception of technology) affect technology integration in EFL classrooms in the Saudi context. This section responds to these questions and offers an interpretation of the results presented in the previous section. In order to explore the findings, descriptive statistics were used to analyse the data provided by participants. A Pearson correlation test was then applied to respond to the research questions.

Regarding the first research question, which concerned the relationship between teacher age and technology integration, the findings suggest that the relationship is not significant. The study supports some existing literature on the impact of age on technology integration (Mahdi 2013; Tweed, 2103). However, Henry (2008) reports that the age of the teacher has a positive effect on technology integration. Concerning this conflict with other existing literature, it should be noted that only 38 teachers participated in this study, $65.8 \%$ of whom were under 40 , and $34.2 \%$ of whom were over 40 . The results may change if both groups had the same number of participants.

Concerning the second research question, which addressed the relationship between teachers' level of technology proficiency and technology integration, the findings suggest a strong correlation. In addition, participants overall showed a high level of technology proficiency. This finding supports the recommendation of Hastings (2009) that educational institutions should provide teachers with professional development that helps teachers to implement technology effectively in the classroom. Hastings (2009) found that teachers who receive professional development in technology tend to integrate technology in their classrooms to a larger extent. Additionally, the present study's findings may be linked to the findings of Al-Asmari (2005). In Al-Asmari's study, the participants had low levels of technology proficiency, and technology integration was low; moreover, participants expressed the need to be provided with training.

Finally, regarding the last research question, which concerned the relationship between teachers' perceptions towards technology and technology integration, the findings suggest a strong relationship. In addition, the participants had a positive perception of technology integration. Namely, $65.8 \%$ of the teachers viewed technology as a supportive tool that helps to ease pressure on the teacher (see Table 3). These participants also perceived technology as a method that improves students' understanding. Therefore, the teachers prefer to integrate technology in their classrooms. These findings can be linked to those of Mollaie and Riasati (2013) and Aydin (2013), who found that technology enhances learning. Moreover, it is important to note that the current study suggests that teachers in the Saudi EFL context are confident about technology integration in the class, which is significantly different from the results of Saqlani and Mahmood (2013), who found that Saudi EFL teachers were anxious about integrating technology in their classrooms.

Finally, the researcher is aware that this study has a number of limitations. Those limitations include the low number of participants and the unequal number of participants from different age groups. There were a larger number of younger participants (under the age of 40) than older participants (over the age of 40). Another limitation is that the study used an online questionnaire. This questionnaire may not have reached teachers who do not use technology.

\section{Conclusion}

This study investigated the influence of teachers' age, level of technology proficiency, and perceptions of technology on technology integration in Saudi EFL classrooms. The findings of this study suggest that there is no significant relationship between teacher age and technology integration. In contrast, the findings do show a significant relationship between technology integration in Saudi EFL classrooms and both teachers' level of technology proficiency and teachers' perception of technology. Therefore, it is recommended to provide teachers with professional development and support in technology integration. It is also recommended to supply classrooms with different resources such as computers and smartboards.

It is recommended that further future research may consider investigating other factors such as teachers' gender and teachers' experience in other specific contexts. 


\section{References}

Ahmadi, D., \& Reza, M. (2018). The use of technology in English language learning: A literature review. International Journal of Research in English Education, 3(2), 115-125. https://doi.org/10.29252/ijree.3.2.115

Al-Asmari, A. M. (2005). The use of the Internet among EFL teachers at the colleges of technology in Saudi Arabia (Doctoral dissertation, The Ohio State University).

Alsaied, H. I. K. (2016). Use of blackboard application in language teaching: Language teachers' perceptions at KAU. International Journal of Applied Linguistics and English Literature, 5(6), 43-50. https://doi.org/10.7575/aiac.ijalel.v.5n.6p.43

Aydin, S. (2013). Teachers' perceptions about the use of computers in EFL teaching and learning: the case of Turkey. Computer Assisted Language Learning, 26(3), 214-233.

Çebi, A. (2018). Teachers' Perceptions Toward Technology Integration into the Language Teaching Practices. Journal of Narrative and Language Studies, 6(11), 150-177. https://doi.org/10.1080/09588221.2012.654495

Dörnyei, Z. (2007). Research methods in applied linguistics: Quantitative, qualitative, and mixed methodologies (pp. 95-123). Oxford: Oxford University Press.

Hastings, T. A. (2009). Factors that predict quality classroom technology use (Doctoral dissertation, Bowling Green State University).

Henry, A. M. (2008). The relationship of age, gender, and personality style with the level of technology implementation at the university level. Walden University.

Jones, A. (2004). A review of the research literature on barriers to the uptake of ICT by teachers.

Mahdi, H. S., \& Al-Dera, A. S. A. (2013). The Impact of Teachers' Age, Gender and Experience on the Use of Information and Communication Technology in EFL Teaching. English Language Teaching, 6(6), 57-67. https://doi.org/10.5539/elt.v6n6p57

Mollaei, F., \& Riasati, M. J. (2013). Teachers' perceptions of using technology in teaching EFL. International Journal of Applied Linguistics and English Literature, 2(1), 13-22. https://doi.org/10.7575/ijalel.v.2n.1p.13

O'Reilly, E. (2016). Developing technology needs assessments for educational programs: An analysis of eight key indicators. International Journal of Education and Development using ICT, 12(1).

Pallant, J. (2013). SPSS survival manual. McGraw-Hill Education (UK).

Pourhosein Gilakjani, A., \& Sabouri, N. B. (2014). Role of Iranian EFL teachers about using Pronunciation Power Software in the instruction of English pronunciation. English Language Teaching, 7(1), 139-148. https://doi.org/10.5539/elt.v7n1p139

Saqlain, N., \& Mahmood, Z. (2013). English Language Instructors' Perceptions about Technology-Based Language Learning at Northern Border University in Saudi Arabia. Turkish Online Journal of Educational Technology-TOJET, 12(2), 106-110.

The Centre for the Study of Learning and Performance (CSLP). Technology Implementation Questionnaire: Version II. (n.d.) Retrieved from https://www.concordia.ca/content/dam/artsci/research/cslp/docs/TIQ2.pdf

Tweed, S. R. (2013). Technology implementation: Teacher age, experience, self-efficacy, and professional development as related to classroom technology integration.

Zhao, Y., Pugh, K., Sheldon, S., \& Byers, J. L. (2002). Conditions for classroom technology innovations. Teachers college record, 104(3), 482-515. https://doi.org/10.1111/1467-9620.00170 


\section{Appendix}

Questionnaire:

\section{1- Teachers' age:}

1. Your age range is between:

1. Under 40

2. Over 40

\section{2- Teachers' perceptions and views of technology:}

1. The use of technology eases the pressure on me as a teacher

2. Technology plays an important role in the learning process.

3. The use of technology improves students' understanding of the lesson.

4. Technology is a valuable instructional tool.

5. Technology motivates students to get more involved in the learning process.

6. The use of technology results in students neglecting important traditional learning resources (e.g. library books).

7. Technology requires software-skills training that is too time consuming.

\section{3- Teachers' level of technology proficiency:}

1. I can apply what I know about technology in the classroom.

2. I am able to use technology as an instructional aid and have integrated technology into the curriculum.

3. I can use many different computer applications.

4. I am proficient in using a wide variety of computer technologies.

5. I integrate computer technologies in my teaching activities.

6. I feel that I need more training in the use of technology for teaching.

7. It is hard for me to implement technology in class.

4- Implementation of technology in class:

1. I use a variety of strategies for implementing technology into my curriculum.

2. I plan and integrate technology-based learning activities that promote student engagement in higher-order thinking skills.

3. I try to use as much computer applications as I can.

4. I use new technologies in class.

5. I introduce my students to new technologies.

6. I integrate technology that help to improve the students' understanding.

7. Technology is a fundamental component of my class.

\section{Copyrights}

Copyright for this article is retained by the author(s), with first publication rights granted to the journal.

This is an open-access article distributed under the terms and conditions of the Creative Commons Attribution license (http://creativecommons.org/licenses/by/4.0/). 